\title{
Evaluation of inert markers for the determination of ileal and faecal apparent digestibility values in the pig
}

\author{
BY S. JAGGER ${ }^{1 *}$, J. WISEMAN ${ }^{1 \dagger}$, D. J. A. COLE ${ }^{1}$ AND J. CRAIGON ${ }^{2}$ \\ ${ }^{1}$ Department of Agriculture and Horticulture and ${ }^{2}$ Department of Physiology and Environmental \\ Studies, University of Nottingham, Faculty of Agricultural and Food Sciences, Sutton Bonington, \\ Loughborough, Leics LE12 $5 R D$
}

(Received 4 January 1991-Accepted 29 October 1991)

\begin{abstract}
A series of experiments was designed to evaluate inert markers employed in studies of ileal and faecal apparent digestibilities of nitrogen and amino acids in pigs fitted with simple ' $T$ ' piece cannulas. Trial 1 assessed the palatability of diets containing (a) $5 \mathrm{~g}$ chromic oxide $/ \mathrm{kg},(b) 1$ and (c) $5 \mathrm{~g}$ titanium dioxide $/ \mathrm{kg}$ at two levels of feeding. The results indicated that there were slight problems in terms of period of feed consumption associated with diets $(a)$ and $(c)$, but that these effects were transitory and disappeared following acclimatization, although higher levels of feeding may compound the problem. Trial 2 estimated $N$ balance, faecal apparent digestibility of amino acids as determined by both total collection and ratio of markers, ileal apparent digestibility of amino acids and recovery of markers using diets containing (a) 1 and (b) $5 \mathrm{~g} \mathrm{Cr}_{2} \mathrm{O}_{3} / \mathrm{kg},(c) 1$ and (d) $5 \mathrm{~g} \mathrm{TiO}_{2} / \mathrm{kg}$. An additional assessment of acidinsoluble lignin present within the diet was also undertaken. $\mathrm{Cr}_{2} \mathrm{O}_{3}$ was associated with the lowest recovery, whilst calculations based on $\mathrm{TiO}_{2}$ gave lower standard errors. Trial 3 examined diurnal variation in digesta sampling and its effect on faecal apparent digestibility of $\mathbf{N}$ and amino acids. There were no evident effects. In general, it was concluded that the most appropriate marker to use in studies of this nature was $\mathrm{TiO}_{2}$ at a rate of $1 \mathrm{~g} / \mathrm{kg}$.
\end{abstract}

Inert markers: Ileal digestibility: Faecal digestibility: Pig

Inert markers are frequently employed in digestibility studies. They provide a means of calculating the digestibility of a nutrient when the complete collection of digesta from a known quantity of feed consumed cannot be undertaken. The use of inert markers is, therefore, essential with ileal digestibility studies employing simple ' $\mathrm{T}$ ' piece cannulas to obtain a sample of digesta. They may also be used to check and correct any loss of material during total collection of ileal digesta via re-entrant cannulas.

A detailed review has been made of the efficacy of various markers used in digestibility studies (Kotb \& Luckey, 1972). Maynard et al. (1979) stated that an ideal marker for the determination of digestibility values should have the following properties: (1) totally indigestible and unabsorbable, (2) pharmacologically inactive within the digestive tract, (3) pass through the tract at a uniform rate, (4) readily determined chemically, (5) preferably a substance naturally present in the feed.

The recovery of the marker, which is the quantity collected from the total collection of faeces expressed as a proportion of that consumed, is an important indication of its efficacy. Ideally the recovery value should be 1.00 or, at least, a constant value which would allow the use of a correction factor in the calculation of digestibility. Chromic oxide is the most widespread marker used in studies with pigs (Low, 1982). However, it has been associated with many problems. It has variable recovery rates (Moore, 1957), has carcinogenic

* Present address: Dalgety Agriculture Ltd., 180 Aztec West, Almondsbury, Bristol BS12 4TH.

$\dagger$ For reprints. 
Table 1. Composition of the diet $(\mathrm{g} / \mathrm{kg})$

\begin{tabular}{lr}
\hline \hline Barley & $421 \cdot 6$ \\
Wheat & $332 \cdot 1$ \\
Soya-bean meal $(440 \mathrm{~g} \mathrm{CP} / \mathrm{kg})$ & $168 \cdot 4$ \\
Fish meal $(630 \mathrm{~g} \mathrm{CP} / \mathrm{kg})$ & $52 \cdot 6$ \\
Vitamin-mineral supplement*† & $12 \cdot 5$ \\
Betamix $192^{*}$ & $1 \cdot 0$ \\
Salt & $2 \cdot 1$ \\
& $1 \cdot 0$ \\
& $8 \cdot 7$ \\
\hline
\end{tabular}

$\mathrm{CP}$, crude protein (nitrogen $\times 6 \cdot 25$ ).

* BP Nutrition (UK) Ltd, Cheshire.

$\dagger$ Containing (mg/kg): vitamin A 1939 , vitamin D 4800 , vitamin E 800, sodium $14 \mathrm{~g}$, calcium $240 \mathrm{~g}$, selenium 8 .

properties (Peddie et al. 1982), and can oxidize unsaturated fats (Steele \& Clapperton, 1982). Other metal oxides have been employed in digestibility studies. Titanium dioxide may have potential as an inert marker, but the review by Kotb \& Luckey (1972) indicated that more experimentation was required before its value could be assessed. Indeed, there would appear to have been no reports on its use in pig digestibility studies and, since it has the advantage of being able to be determined during the analysis for nitrogen, such a marker would save considerable time and expense during laboratory procedures associated with assessments of digestibility.

Ideally an inert marker of dietary origin such as lignin would be the most convenient to use. It is associated with high rates of recovery (Kane et al. 1950), although it is very difficult to quantify accurately. The objective of the trials reported here was a comprehensive appraisal of inert markers employed in studies of ileal apparent digestibility of amino acids determined with pigs fitted with simple ' $T$ ' piece cannulas.

\section{MATERIALS AND METHODS}

Trial 1. Investigation into the palatability of $\mathrm{TiO}_{2}$ and $\mathrm{Cr}_{2} \mathrm{O}_{3}$

Preliminary investigations had revealed problems of palatability when pigs were fed diets containing metal markers. This trial was designed to quantify any such effect which could be important in subsequent studies.

Animals and treatments. Sixteen boars and sixteen gilts (Landrace $\times$ (Landrace $\times$ Large White)), with an initial live weight of approximately $57 \mathrm{~kg}$, obtained from the enzootic pneumonia-free herd at the University of Nottingham were housed in four pens each fitted with individual feeders. Four boars and four gilts were placed in each pen. Following an acclimatization period of $7 \mathrm{~d}$, one boar and one gilt from each pen were randomly allocated to one of four treatments. These consisted of a single diet (Table 1) supplemented with $(a)$ $5 \mathrm{~g} \mathrm{Cr}_{2} \mathrm{O}_{3} / \mathrm{kg}$, (b) 1 and $(c) 5 \mathrm{~g} \mathrm{TiO}_{2} / \mathrm{kg}$. The fourth treatment was the diet with no addition of metal marker. Each treatment was offered twice daily at 09.00 and 16.00 hours with water in the ratio $1: 2 \cdot 5(\mathrm{w} / \mathrm{v})$. Additional water was available ad lib.

Procedure. Over the first $11 \mathrm{~d}$ of the trial, the restricted feeding scale used by Morgan (1972; Table 2) was employed. Each animal was weighed weekly and the appropriate quantity of food given. After weighing the appropriate amount of each diet at each feed for each pig, the required quantity of inert marker was weighed and mixed thoroughly with the diet before presentation to the animals. Such a procedure removed the possible effect of 
Table 2. Feeding scale used in digestibility trials in pigs

\begin{tabular}{ccc}
\hline \hline & \multicolumn{2}{c}{$\begin{array}{c}\text { Food allowance } \\
(\mathrm{kg} / \mathrm{d})\end{array}$} \\
\cline { 2 - 3 } $\begin{array}{c}\text { Live wt } \\
(\mathrm{kg})\end{array}$ & $\begin{array}{c}\mathrm{A} \\
(\text { Morgan, 1972) }\end{array}$ & $\begin{array}{c}\text { B } \\
\text { (Agricultural Research Council, 1981) }\end{array}$ \\
$55-60$ & $2 \cdot 000$ & $2 \cdot 260$ \\
$60-65$ & $2 \cdot 100$ & $2 \cdot 400$ \\
$65-70$ & $2 \cdot 195$ & $2 \cdot 520$ \\
$70-75$ & $2 \cdot 295$ & $2 \cdot 610$ \\
$75-80$ & $2 \cdot 385$ & $2 \cdot 730$ \\
\hline
\end{tabular}

poor distribution of marker within each diet. The time-period taken for each pig to consume each meal completely was recorded up to $60 \mathrm{~min}$; this was assumed to be the timeperiod a healthy pig with no problems of diet palatability would need to consume all its food. If any feed remained after this time-period the meal was considered a refusal. After each meal all food troughs were cleaned thoroughly. After $11 \mathrm{~d}$ of this phase of the experiment, a higher feeding scale based on dietary energy requirements (Agricultural Research Council, 1981) was offered for a further $7 \mathrm{~d}$ and the time taken for complete consumption recorded as previously stated.

The analysis of variance for the trial was based on the logarithm of the time-period taken to eat each meal (to produce a normal distribution) and a censored analysis procedure (Taylor, 1973) within GENSTAT 5 was employed to account for those meals not completed in the time allotted. The censoring procedure included the fact that the timeperiod taken to consume some meals was longer than $60 \mathrm{~min}$ rather than substitute missing values for these data points.

\section{Trial 2. Evaluation of $\mathrm{Cr}_{2} \mathrm{O}_{3}, \mathrm{TiO}_{2}$ and lignin as inert markers for use in pig digestibility} studies

This trial was designed to evaluate the suitability of different mineral markers for the determination of apparent digestibility values of $\mathrm{N}$ and amino acids.

Animals and treatments. Five gilts were selected for the experiment and were surgically fitted with simple ' $T$ ' piece cannulas at the terminal ileum. The procedure has been described fully by Jagger (1987). After recovery from cannulation all animals had a live weight of approximately $35 \mathrm{~kg}$. The diet (Table 1) was then offered at a restricted level (Table 2) for a period of $7 \mathrm{~d}$ during which time the animals were allowed to adapt to their environment.

One of the following levels and types of mineral marker were added to the diet producing five experimental treatments, including the diet containing no added marker for the determination of lignin: (a) 1 and (b) $5 \mathrm{~g} \mathrm{Cr}_{2} \mathrm{O}_{3} / \mathrm{kg}$, (c) 1 and (d) $5 \mathrm{~g} \mathrm{TiO}_{2} / \mathrm{kg}$, (e) grower diet with no added marker. Each animal received each treatment according to a $5 \times 5$ Latin square.

Procedure. All pigs were fed at 08.00 and 20.00 hours throughout the trial and feed was mixed with water in the ratio $1: 2(\mathrm{w}: \mathrm{v})$. An appropriate amount of each of the inert markers was weighed, added to each individual bag for each pig containing the quantity of feed for each meal and thoroughly mixed before feeding.

At $3 \mathrm{~d}$ after offering the experimental diets all animals were placed in metabolism crates fitted with sliding Perspex sheets to allow access to the cannulas. Faeces were collected from 
Table 3. Trial 1. Intercept and slope of regression lines relating censored logarithm of time-period taken to consume a meal v. meal number in pigs given inert markers during digestibility trials

\begin{tabular}{|c|c|c|c|c|c|c|}
\hline \multirow{2}{*}{\multicolumn{2}{|c|}{ Marker $(\mathrm{g} / \mathrm{kg}$ diet $) \ldots$}} & \multirow{2}{*}{$\begin{array}{c}\text { Chromic oxide } \\
5\end{array}$} & \multicolumn{2}{|c|}{ Titanium dioxide } & \multirow[b]{2}{*}{ Control } & \multirow[b]{2}{*}{ Mean } \\
\hline & & & 5 & 1 & & \\
\hline \multicolumn{7}{|c|}{ Feed level $A^{*}$} \\
\hline \multirow{2}{*}{\multicolumn{2}{|c|}{$\begin{aligned} \text { Sex: } & \text { Male } \\
& \text { Female }\end{aligned}$}} & 2.75 & $3 \cdot 44$ & $2 \cdot 51$ & 2.49 & $2 \cdot 80$ \\
\hline & & $3 \cdot 14$ & $3 \cdot 35$ & $2 \cdot 61$ & $2 \cdot 67$ & $2 \cdot 94$ \\
\hline \multirow{5}{*}{\multicolumn{2}{|c|}{ Mean }} & $2 \cdot 95$ & $3 \cdot 40$ & \multirow{2}{*}{$P={ }^{2 \cdot 56}$} & $2 \cdot 58$ & - \\
\hline & & Factor & SED & & & \\
\hline & & Sex & 0.017 & $0 \cdot 40$ & & \\
\hline & & Treatment & 0.024 & & & \\
\hline & & Sex $\times$ treatment & 0.034 & $\begin{array}{l}0.006 \\
0.79\end{array}$ & & \\
\hline \multicolumn{7}{|l|}{ Slope } \\
\hline \multirow[t]{7}{*}{ Sex: } & Male & -0.021 & -0.058 & $8-0.001$ & $-0 \cdot 024$ & -0.026 \\
\hline & Female & -0.045 & $-0 \cdot 036$ & $6-0.029$ & 0.006 & -0.026 \\
\hline & \multirow[t]{5}{*}{ Mean } & -0.033 & \multicolumn{2}{|c|}{$-0.047-0.015$} & -0.009 & - \\
\hline & & Factor & SED & $P=\dagger$ & & \\
\hline & & \multirow{2}{*}{$\begin{array}{l}\text { Sex } \\
\text { Treatment }\end{array}$} & $0 \cdot 011$ & 1.00 & & \\
\hline & & & 0.016 & 009 & & \\
\hline & & Sex $\times$ treatment & 0.022 & $0 \cdot 18$ & & \\
\hline \multicolumn{7}{|c|}{ Feed level $\mathbf{B}^{*}$} \\
\hline \multicolumn{7}{|c|}{ Intercept } \\
\hline \multirow{2}{*}{\multicolumn{2}{|c|}{$\begin{array}{l}\text { Sex: Male } \\
\text { Female }\end{array}$}} & $2 \cdot 07$ & $2 \cdot 48$ & $2 \cdot 05$ & $2 \cdot 15$ & $2 \cdot 19$ \\
\hline & & $2 \cdot 44$ & $3 \cdot 40$ & $2 \cdot 08$ & $2 \cdot 56$ & $2 \cdot 62$ \\
\hline & Mean & $2 \cdot 26$ & $2 \cdot 94$ & $2 \cdot 06$ & $2 \cdot 36$ & - \\
\hline & & Factor & SED & $P=\dagger$ & & \\
\hline & & Sex & $0 \cdot 24$ & $0 \cdot 10$ & & \\
\hline & & Treatment & 0.34 & 0.11 & & \\
\hline & & Sex $\times$ treatment & 0.49 & 0.65 & & \\
\hline Slope & & & & & & \\
\hline Sex: & Male & $0 \cdot 033$ & $0 \cdot 049$ & 0.002 & -0.007 & 0.019 \\
\hline & Female & $0 \cdot 062$ & 0.038 & 0.002 & 0.002 & 0.026 \\
\hline & Mean & 0.047 & $0 \cdot 044$ & 0.002 & -0.003 & - \\
\hline & & Factor & SED & $P=\dagger$ & & \\
\hline & & Sex & $0 \cdot 016$ & 0.71 & & \\
\hline & & Treatment & 0.023 & 0.09 & & \\
\hline & & Sex $\times$ treatment & 0.033 & 0.85 & & \\
\hline
\end{tabular}

SED, standard error of differences

* For details, see Table 2.

$\dagger$ Probability that the differences in mean data for the factors in question occurred by chance.

days 5 to 9 inclusive for the determination of the time-period (d) required for the marker to be excreted at a constant rate. The first of the five collection periods commenced $9 \mathrm{~d}$ after introduction of the experimental diets. A marker-to-marker collection of faeces was undertaken over a period of $5 \mathrm{~d}$ using ferric oxide added to diets at a rate of $20 \mathrm{~g} / \mathrm{kg}$. Urine was collected quantitatively over a $5 \mathrm{~d}$ period. Following faecal collection, approximately $50 \mathrm{~g}$ ileal digesta were collected from each animal on days 1,3 and 5 at 2, 4, 6, 8, 10, and $12 \mathrm{~h}$ following the morning feed. Once the collection of the ileal digesta was completed, 
each animal was removed from the metabolism crate, weighed and immediately allocated the new experimental diet at the level prescribed by live weight. A further $9 \mathrm{~d}$ acclimatization period preceded the second collection period as described previously. Collection periods 3 , 4 and 5 followed the same routine.

The experiment allowed several comparisons to be made between the markers: (a) effect of marker on $\mathrm{N}$ balance and faecal apparent digestibility of $\mathrm{N}$ and amino acids determined by the total collection of faeces, (b) the recovery of markers, (c) the faecal apparent digestibility values of $\mathrm{N}$ and amino acids determined by the use of markers and those obtained by total faecal collection and (d) the effect of marker on the ileal apparent digestibility values of $\mathrm{N}$ and amino acids.

\section{Trial 3. Diurnal variation of ileal apparent digestibility values of amino acids}

The objective of this trial was to evaluate the effect of time of sampling of ileal digesta postprandially on the calculation of apparent digestibility. Samples of digesta collected in trial 2 from pigs receiving $5 \mathrm{~g} \mathrm{Cr}_{2} \mathrm{O}_{3} / \mathrm{kg}, 5 \mathrm{~g} \mathrm{TiO}_{2} / \mathrm{kg}$ and no added marker during collection periods 1 and 4 were used for this experiment. Samples were collected on days 1, 3 and 5 at $2,4,6,8,10$ and $12 \mathrm{~h}$ post prandially. Each sample obtained was analysed for those amino acids considered essential for the pig, with the exception of tryptophan. Determination of the content of inert marker allowed the calculation of the ileal apparent digestibility of these amino acids.

\section{Analytical procedures}

Amino acids. Samples of $0.5 \mathrm{~g}$ were refluxed for $22 \mathrm{~h}$ in $300 \mathrm{ml} 6 \mathrm{M}$-hydrochloric acid in an atmosphere of $\mathrm{N}_{2}$. Following cooling, the hydrolysate was made up to $500 \mathrm{ml}$ with the addition of distilled water and a filtered portion taken, the volume of which was based on the expected concentration of the amino acids present in solution. Nor-leucine $(1 \mu \mathrm{g})$ was added as an internal marker before evaporation to dryness at $37^{\circ}$. The sample was washed twice with distilled water before being dissolved in $5 \mathrm{ml}$ lithium citrate loading buffer at $\mathrm{pH}$ 2.2. Samples were stored frozen until analysis.

Methionine and cystine tend to break down during acid-hydrolysis. Accordingly they were oxidized and determined as methionine sulphone and cysteic acid respectively. Samples of $0.1 \mathrm{~g}$ were allowed to stand at $0^{\circ}$, after addition of $10 \mathrm{ml}$ performic acid, for $18 \mathrm{~h}$. While still cold, $1.5 \mathrm{ml}$ hydrobromic acid $(480 \mathrm{ml} / \mathrm{l})$ were added and evaporated to dryness at $37^{\circ}$. Each sample was then refluxed in $30 \mathrm{ml} 6 \mathrm{M}$-hydrochloric acid in an oil bath for $24 \mathrm{~h}$. After cooling, each sample was made up to $50 \mathrm{ml}$. Nor-leucine $(2 \mu \mathrm{M})$ was added to a filtered portion which was evaporated to dryness at $37^{\circ}$, washed twice with distilled water and dissolved in $5 \mathrm{ml}$ lithium citrate loading buffer. The samples were stored frozen until analysis.

All samples were run on an LKB 4400 amino acid analyser using a lithium buffer system. Each sample was pumped through an Aminex A9 column, $250 \mathrm{~mm} \times 4.5 \mathrm{~mm}$, at an elution rate of $20 \mathrm{ml} / \mathrm{h}$. Ninhydrin was pumped through at the same rate. The peak areas were determined using a Spectra Physics SP4270 integrator.

Samples containing $\mathrm{Cr}_{2} \mathrm{O}_{3}$ were analysed using a modified buffer system (BechAnderson, 1979) to prevent the irreversible binding of chromium to the column.

Tryptophan was assayed following the method of Buttery \& Soar (1975).

Inert markers. Samples containing $\mathrm{Cr}_{2} \mathrm{O}_{3}$ were digested according to the method of Marsden (1984), and Cr was determined following the procedure described by Fenton \& Fenton (1979). $\mathrm{TiO}_{2}$ was analysed by the method detailed by Leone (1973). Samples (0.5 g) were digested in $20 \mathrm{ml}$ concentrated sulphuric acid at $42^{\circ}$ on a block digesta. One Kjeltab catalyst tablet was added to each tube. Once the solution had turned emerald-green digestion was continued for a further $30 \mathrm{~min}$ before the tubes were removed. After cooling, 
the volume was made up to $100 \mathrm{ml}$ with distilled water. Following filtration, a $5 \mathrm{ml}$ portion of each sample was taken and $0.2 \mathrm{ml}$ hydrogen peroxide $(300 \mathrm{ml} / \mathrm{l})$ added. The colour produced was measured at $408 \mathrm{~nm}$ using a SP6-500UV spectrophotometer (Peddie et al. 1982) and compared with that produced from a range of standard solutions made up from titanium sulphate. Lignin was determined with the method of Van Soest (1963).

\section{RESULTS}

\section{Trial 1}

The time series nature of the data necessitated the use of regression analysis of the logarithm of time (min) v. meal number (being twenty-three meals in trial 1a and fourteen meals in trial 1b) to detect responses to treatment (Wishart, 1938: Rowell \& Walters, 1976). The variation in both linear trends and departures from linearity between treatment groups was tested against the variation in these trends among replicates on the same treatment groups. In trial $1 \mathrm{~b}$, two pigs within the same pen consistently refused to consume their meals within the time-period allowed, which was unrelated to treatment. Results of the censored analysis were particularly influenced by this and the whole pen was excluded from subsequent analysis.

Results of the analysis of variance are presented in Table 3 for feed levels A and B, in terms of the intercept and slope of the censored logarithm of time-period taken to consume the meal $v$. meal number. Such a response may be viewed as an acclimatization rate, with a negative slope indicating a shorter time-period taken to eat a meal (i.e. acclimatization) and a positive slope being evidence for an increase in time-period taken to consume a meal with time. No non-linear trends had been detected in the earlier analysis of variance.

The results indicated that with pigs fed on level $A$ there was evidence for an effect of treatment ( $P=0.09$ for the slope). The most pronounced response was recorded with those pigs receiving $\mathrm{TiO}_{2}$ at a rate of $5 \mathrm{~g} / \mathrm{kg}$ indicating an initial reluctance to consume meals, but a gradual acclimatization thereafter. Although similar responses were noted for all other treatments, in that slopes were negative, they were less evident for those animals fed on diets based on $\mathrm{Cr}_{2} \mathrm{O}_{3}$ at $5 \mathrm{~g} / \mathrm{kg}$ and of minimal importance for those fed on diets containing $\mathrm{TiO}_{2}$ at $1 \mathrm{~g} / \mathrm{kg}$ and on the control diet. Although no departures from linearity in the responses had been detected in the initial analysis of variance, closer inspection of the data revealed that acclimatization to diets was largely complete following meal 14 .

Responses obtained at the higher rate of feeding (level B) indicated that there was evidence ( $P=0.09$ for the slope) that there was no acclimatization to diets based on either $\mathrm{TiO}_{2}$ or $\mathrm{Cr}_{2} \mathrm{O}_{3}$ at $5 \mathrm{~g} / \mathrm{kg}$. In fact, the time-period taken to consume meals increased with meal number. Results from these pigs fed on diets based on $\mathrm{TiO}_{2}$ at $1 \mathrm{~g} / \mathrm{kg}$ and on the control diet revealed that the time-period taken to consume meals was initially rapid and did not change materially thereafter.

Inspection of the residual mean squares from analyses undertaken separately for the data from each meal time indicated that the variation in time-period taken to consume meals did not alter in any fixed pattern over the course of either experiment.

\section{Trial 2}

There was a significant difference between treatments $(P=0.017)$ in the percentage recovery of markers (Table 4 ). There was a higher recovery of lignin and $\mathrm{TiO}_{2}$ than of $\mathrm{Cr}_{2} \mathrm{O}_{3}$ which had a recovery significantly lower than 1.00 . The addition of a marker to the diet did not significantly affect $\mathrm{N}$ balance $(P=0.294)$, the faecal apparent digestibility of $\mathrm{N}(P=0.831$, Table 4$)$ or the faecal apparent digestibility of individual amino acids (Table 5 ) when determined with the method involving the total collection of faeces. Calculation of 
Table 4. Trial 2. Effect of presence of inert marker on the coefficient of apparent digestibility of nitrogen determined by total faecal collection, $N$ balance and recovery of marker in pigs*

\begin{tabular}{|c|c|c|c|c|c|c|c|}
\hline \multirow[t]{2}{*}{ Marker $(\mathrm{g} / \mathrm{kg}$ diet $) \ldots$} & \multicolumn{2}{|c|}{ Chromic oxide } & \multicolumn{2}{|c|}{ Titanium dioxide } & \multirow{2}{*}{$\begin{array}{l}\text { Lignin } \\
\text { (no added } \\
\text { (marker) }\end{array}$} & \multirow[b]{2}{*}{ SED } & \multirow[b]{2}{*}{$P=\dagger$} \\
\hline & 1 & 5 & 1 & 5 & & & \\
\hline $\begin{array}{l}\text { Apparent faecal } \\
\text { digestibility of } \mathrm{N}\end{array}$ & 0.890 & 0.886 & 0.878 & 0.891 & $0 \cdot 885$ & 0.011 & $0 \cdot 85$ \\
\hline $\mathrm{N}$ balance & $0 \cdot 329$ & 0.180 & 0.216 & $0 \cdot 301$ & 0.260 & 0.073 & 0.29 \\
\hline Marker recovery & 0.746 & 0.797 & 0.983 & 0.969 & 0.981 & $0 \cdot 070$ & $0 \cdot 017$ \\
\hline
\end{tabular}

SED, standard error of differences.

* For details of procedures, see pp. 731-733.

$\mp$ Probability that the differences between treatments (i.e. markers) occurred by chance.

Table 5. Trial 2. Influence of presence of inert marker on coefficient of faecal apparent digestibility of nitrogen and amino acids determined with reference to total faecal collection in pigs*

\begin{tabular}{|c|c|c|c|c|c|c|c|}
\hline \multirow{2}{*}{$\begin{array}{l}\text { Marker }(\mathrm{g} / \mathrm{kg} \text { diet }) . . \\
\text { Amino acid }\end{array}$} & \multicolumn{2}{|c|}{ Chromic oxide } & \multicolumn{2}{|c|}{ Titanium dioxide } & \multirow{2}{*}{$\begin{array}{l}\text { Lignin } \\
\text { (no added } \\
\text { marker) }\end{array}$} & \multirow[b]{2}{*}{ SED } & \multirow[b]{2}{*}{$P=t$} \\
\hline & 1 & 5 & 1 & 5 & & & \\
\hline $\mathrm{N}$ & 0.890 & 0.886 & $0 \cdot 878$ & $0 \cdot 891$ & 0.885 & $0 \cdot 011$ & $0 \cdot 85$ \\
\hline Thr & $0 \cdot 858$ & 0.854 & 0.838 & 0.862 & 0.854 & 0.011 & $0 \cdot 29$ \\
\hline Val & 0.891 & 0.886 & 0.878 & 0.887 & 0.885 & 0.009 & 0.77 \\
\hline Ileu & 0.878 & 0.875 & 0.867 & 0.875 & 0.875 & 0.010 & 0.84 \\
\hline Leu & 0.903 & 0.901 & 0.892 & 0.902 & 0.904 & 0.008 & 0.68 \\
\hline Tyr & 0.903 & 0.898 & $0 \cdot 897$ & 0.901 & 0.899 & 0.009 & 0.97 \\
\hline Phe & 0.908 & 0.910 & 0.899 & 0.907 & 0909 & 0.007 & 0.55 \\
\hline Lys & 0.885 & 0.884 & 0.873 & 0.884 & 0.880 & 0.010 & 0.74 \\
\hline His & 0.929 & 0.931 & 0.930 & 0.930 & 0.922 & 0.009 & 0.84 \\
\hline Met & 0.900 & 0.884 & 0.870 & 0.889 & 0.880 & & \\
\hline Cyst+ & 0.900 & 0.886 & 0.885 & 0.900 & 0.904 & & \\
\hline $\operatorname{Trp}_{+}^{+}$ & 0.947 & 0.838 & 0.941 & 0.946 & 0.946 & & \\
\hline
\end{tabular}

SED, standard error of differences.

* For details of procedures, see pp. 731-733.

Probability that the differences between treatments (i.e. markers) occurred by chance.

+ Data determined with pooled samples.

faecal apparent digestibility of $\mathrm{N}$ and amino acids with reference to markers (Table 6) revealed significant differences between the marker used for all components with the exception of $\mathrm{N}(P=0.094)$ and histidine $(P=0.093)$. Generally, data associated with $\mathrm{Cr}_{2} \mathrm{O}_{3}$ was lower than that derived from both $\mathrm{TiO}_{2}$ and lignin.

The ileal apparent digestibility values of $\mathrm{N}$ and the amino acids determined using each marker are presented in Table 7. Significant differences between markers were obtained for values for $\mathrm{N}$ and individual amino acids. The greatest effect was the considerably lower values obtained with $1 \mathrm{~g} \mathrm{Cr}_{2} \mathrm{O}_{3} / \mathrm{kg}$, but consistently higher values were obtained for the remaining treatments.

Data for faecal apparent digestibility of $\mathrm{N}$ and the essential amino acids calculated using total faecal collection and markers were further analysed as a split-plot design to examine 
Table 6. Trial 2. Coefficient of faecal apparent digestibility of nitrogen and amino acids determined in pigs with reference to markers*

\begin{tabular}{|c|c|c|c|c|c|c|c|}
\hline \multirow{2}{*}{$\begin{array}{l}\text { Marker }(\mathrm{g} / \mathrm{kg} \text { diet }) \ldots \\
\text { Amino acid }\end{array}$} & \multicolumn{2}{|c|}{ Chromic oxide } & \multicolumn{2}{|c|}{ Titanium dioxide } & \multirow{2}{*}{$\begin{array}{l}\text { Lignin } \\
\text { (no added } \\
\text { marker) }\end{array}$} & \multirow[b]{2}{*}{ SED } & \multirow[b]{2}{*}{$P=\emptyset$} \\
\hline & 1 & 5 & 1 & 5 & & & \\
\hline$N$ & 0.852 & 0.855 & $0 \cdot 871$ & 0.874 & $0 \cdot 882$ & 0.011 & 0.09 \\
\hline Thr & 0.809 & 0.845 & $0 \cdot 832$ & 0.842 & 0.851 & 0.009 & 0.004 \\
\hline Val & 0.853 & 0.854 & 0.875 & 0.870 & 0.881 & 0.010 & 0.044 \\
\hline Ileu & 0.836 & 0.838 & 0.863 & 0.857 & 0.872 & 0.011 & 0.025 \\
\hline Leu & 0.869 & 0.873 & $0 \cdot 889$ & 0.887 & 0.898 & 0.007 & 0.011 \\
\hline Tyr & 0.870 & 0.870 & 0.894 & 0.887 & 0.896 & 0.008 & 0.014 \\
\hline Phe & 0.876 & 0.884 & 0.896 & 0.893 & 0.907 & 0.007 & 0.005 \\
\hline Lys & 0.845 & 0.849 & 0.869 & 0.867 & 0.877 & 0.009 & 0.024 \\
\hline His & 0.904 & 0.912 & 0.928 & 0.919 & 0.920 & 0.008 & 0.09 \\
\hline Met & 0.846 & 0836 & 0.852 & 0.857 & 0.862 & & \\
\hline Cysł & 0.848 & 0.839 & 0.869 & 0.870 & 0.890 & & \\
\hline Trpt & 0.920 & 0.812 & 0.933 & 0.930 & 0.938 & & \\
\hline
\end{tabular}

SED, standard error of differences.

* For details of procedures, see pp. 731 733.

$\uparrow$ Probability that the differences between treatments (i.e. markers) occurred by chance.

\$ Data determined with pooled samples.

Table 7. Trial 2. Coefficient of ileal apparent digestibility of nitrogen and amino acids determined with markers in pigs*

\begin{tabular}{|c|c|c|c|c|c|c|c|}
\hline \multirow{2}{*}{$\begin{array}{l}\text { Marker (g/kg diet)... } \\
\text { Amino acid }\end{array}$} & \multicolumn{2}{|c|}{ Chromic oxide } & \multicolumn{2}{|c|}{ Titanium dioxide } & \multirow{2}{*}{$\begin{array}{l}\text { Lignin } \\
\text { (no added } \\
\text { marker) }\end{array}$} & \multirow[b]{2}{*}{ SED } & \multirow[b]{2}{*}{$P=\dagger$} \\
\hline & 1 & 5 & j & 5 & & & \\
\hline$N$ & 0.529 & 0.701 & 0.799 & 0.768 & 0.725 & 0.059 & 0.006 \\
\hline Thr & $0 \cdot 340$ & 0.618 & 0.718 & 0.704 & 0.654 & 0.064 & 0.001 \\
\hline Val & 0.574 & 0.730 & 0.808 & 0.786 & 0.724 & 0.060 & 0.017 \\
\hline Ileu & 0.541 & 0.714 & 0.797 & 0.801 & 0.736 & 0.050 & 0.001 \\
\hline Leu & 0.602 & 0.752 & 0.822 & 0.825 & 0.761 & 0.049 & 0.004 \\
\hline Tyr & 0.613 & $0 \cdot 811$ & 0.830 & 0.840 & 0.800 & 0.053 & 0.006 \\
\hline Phe & 0.659 & 0.775 & 0.837 & 0.843 & 0.805 & 0.042 & 0.006 \\
\hline Lys & 0.575 & 0.719 & 0.800 & 0.806 & 0.734 & 0.043 & 0.001 \\
\hline His & 0.667 & 0.776 & 0.844 & 0.848 & 0.834 & 0.053 & 0.027 \\
\hline Mett & 0.711 & 0.811 & 0.843 & 0.847 & 0.853 & & \\
\hline Cyst & 0.487 & 0.664 & 0.741 & 0.693 & 0.716 & & \\
\hline Trpt & 0.666 & 0.787 & 0.852 & 0.832 & 0.774 & & \\
\hline
\end{tabular}

SED, standard error of differences.

* For details of procedures, see pp. 731-733.

$\uparrow$ Probability that the differences between treatments (i.e. markers) occurred by chance.

$\$$ Data determined with pooled samples.

any differences between the two means of derivation of apparent faecal digestibility. A significantly greater value was obtained for the former method in all cases with both $\mathrm{N}$ and all amino acids (SE for the differences (SED) between the two methods ranging from 0.002 to 0.004 with $P<0.001$ in all cases). However, significant method $\times$ treatment interactions were also found between the differences in faecal apparent digestibility for each amino acid and N. The pattern observed was consistent (SED ranging from 0.007 to 0.012 , and $P$ ranging 
from 0.006 to 0.012 ). Faecal apparent digestibility values calculated using both 1 and $5 \mathrm{~g}$ $\mathrm{Cr}_{2} \mathrm{O}_{3} / \mathrm{kg}$ showed greater differences than those obtained from $5 \mathrm{~g} \mathrm{TiO} / \mathrm{kg}$ and lignin. Faecal apparent digestibility values calculated from $1 \mathrm{~g} \mathrm{TiO}_{2} / \mathrm{kg}$ and lignin showed the smallest difference from those obtained by total faecal collection.

Differences between the faecal and ileal apparent digestibilities of $\mathrm{N}$ and amino acids using markers were examined in a similar fashion by comparing both data sets in a splitplot design. Values obtained with the former method were significantly higher (with SED ranging from 0.013 to 0.021 and $P<0.001$ in all cases). Significant treatment $\times$ method interactions were also obtained for each amino acid and $N$ (SED ranging from 0.030 to 0.048 and $P$ ranging from $<0.001$ to 0.006 ). The greatest difference between the two methods was observed when the calculation was based on $1 \mathrm{~g} \mathrm{Cr}_{2} \mathrm{O}_{3} / \mathrm{kg}$ and the lowest with both $\mathrm{I}$ and $5 \mathrm{~g} \mathrm{TiO}_{2} / \mathrm{kg}$.

Over the five collection periods residuals from the analysis of variance were saved and their variances calculated. Faecal apparent digestibility values were associated with similar errors throughout. Although the differences in standard errors for ileal apparent digestibility values were not considered sufficiently large to invalidate the analysis of variance (effects were associated with very low values for $P$; Table 7 ), it was evident that those associated with $\mathrm{TiO}_{2}$ were lower than with $\mathrm{Cr}_{2} \mathrm{O}_{3}$.

\section{Trial 3}

There were no significant differences between times of collection (with the exception of phenylalanine, $P=0.015$ ), time $\times$ marker interactions (with the exception of phenylalanine, $P=0.022$ ), day of collection or marker $\times$ days interactions. The seemingly anomalous result for phenylalanine was attributable to a low value obtained for ileal apparent digestibility at one particular time of digesta collection when lignin was used for the calculation of apparent digestibility. This indicates that lignin was out of phase with phenylalanine.

\section{DISCUSSION}

There was an indication that both $\mathrm{Cr}_{2} \mathrm{O}_{3}$ and $\mathrm{TiO}_{2}$ present in the diet at $5 \mathrm{~g} / \mathrm{kg}$ caused an initial reduction in the rate of food consumption with feeding level $\mathrm{A}$. This effect was, however, somewhat transitory, and was certainly overcome within typical acclimatization periods of 7-10 d. This acquired tolerance to markers was, however, not continued into the second phase of trial 1 when a higher level of food was offered. Thus, diets based on both $\mathrm{TiO}_{2}$ and $\mathrm{Cr}_{2} \mathrm{O}_{3}$ at $5 \mathrm{~g} / \mathrm{kg}$ were consumed at a relatively slower rate which did not increase with meal number. Diets containing $\mathrm{TiO}_{2}$ at $1 \mathrm{~g} / \mathrm{kg}$ were indistinguishable from the control diet.

Although Peers et al. (1977) were able to conclude that levels of feeding ranging from maintenance to three times maintenance had no effect on the faecal apparent digestibility of both dietary energy and $\mathrm{N}$, there are conflicting reports on the importance of feed consumption in digestibility studies. Changes in rates of intake may influence the quantity of endogenous material secreted and hence apparent digestibility values obtained. Corring (1980) observed that increased feed intake was associated with a rise in the volume of saliva secreted and Tanksley et al. (1981) found that increasing feed intake caused a slight but consistent rise in the ileal apparent digestibility of $\mathrm{N}$. This may indicate that the quantity of endogenous protein secreted per unit of feed consumed is reduced as the quantity of feed consumed increases. In view of the uncertain effects of variation in the quantity of food consumed on the apparent digestibility values obtained it is essential that intake is kept constant. In addition it is important that the time-period allowed for the consumption of the feed is such that a given meal is not recognized as a series of smaller meals. Thus, if a 
single meal is in fact consumed as a series of smaller individual meals then this may influence endogenous protein secretions with a resultant effect on the estimation of apparent digestibility.

Recovery of markers is a crucial aspect of their suitability for use in the determination of digestibility values. Findings from the present trial indicated that $\mathrm{Cr}_{2} \mathrm{O}_{3}$ gave significantly lower recoveries than $\mathrm{TiO}_{2}$ and lignin, which has been attributed to fineness of grinding of the marker leading to its retention by the gastrointestinal tract (Barnicote, 1945; Moore, 1959). In contrast, Lloyd et al. (1955) reported recoveries of 0.998 for $\mathrm{Cr}_{2} \mathrm{O}_{3}$ in pigs, considerably higher than those in the present study. There would not appear to be any explanation for these differences, although it is likely that variability in methodology between experimental programmes is a probable cause. High recoveries of $\mathrm{TiO}_{2}$ have been reported in the rat by $\mathrm{Njaa}$ (1961) and in the chick by Peddie et al. (1982).

The effect of variability in marker recovery on the difference between apparent digestibility of nutrients determined through total collection and with a marker was clear. The marker with the lowest recovery, $\mathrm{Cr}_{2} \mathrm{O}_{3}$, was associated with the greatest difference between the two methods. Furthermore, examination of the standard errors associated with apparent ileal digestibility values calculated using each marker revealed that the lowest values were obtained with $\mathrm{TiO}_{2}$ and the greatest with $\mathrm{Cr}_{2} \mathrm{O}_{3}$ at a level of $1 \mathrm{~g} / \mathrm{kg}$ diet.

Diurnal variation in the quantity of $\mathrm{Cr}_{2} \mathrm{O}_{3}$ per unit faecal dry matter was shown by Moore (1957) to be influenced by the interval between feeding, the individual pig and the length of time spent eating. This effect may be attributable in all likelihood to the marker not moving in phase with digesta. However, the results of the present trial indicated that there was no influence of day of sampling on apparent digestibility of amino acids and that there was no marker $x$ day interaction. Similarly, no consistent effects of time of sampling were evident. Accordingly there did not appear to be any difference between $\mathrm{Cr}_{2} \mathrm{O}_{3}$ and $\mathrm{TiO}_{2}$ at $5 \mathrm{~g} / \mathrm{kg}$ diet as markers.

From the evidence collected during the present investigations, the choice of a suitable marker for the calculation of apparent digestibility of amino acids in diets for pigs rests with lignin, $\mathrm{Cr}_{2} \mathrm{O}_{3}$ at $5 \mathrm{~g} / \mathrm{kg}$ or $\mathrm{TiO}_{2}$ at 5 or $1 \mathrm{~g} / \mathrm{kg}\left(1 \mathrm{~g} \mathrm{Cr}_{2} \mathrm{O}_{3} / \mathrm{kg}\right.$ being unsuitable).

Initial studies on palatability indicated that $\mathrm{TiO}_{2}$ and, to an extent, $\mathrm{Cr}_{2} \mathrm{O}_{3}$ at levels of $5 \mathrm{~g} / \mathrm{kg}$ were associated with slower rates of feed consumption. Acclimatization to these two markers was more apparent at lower levels of feed intake.

The use of $\mathrm{Cr}_{2} \mathrm{O}_{3}$ was associated with lower recoveries, smaller values for faecal apparent digestibility and larger standard errors than the other two markers. Lignin apparently moves out of phase with phenylalanine and is a variable component of feedstuffs. This leads to the conclusion that $\mathrm{TiO}_{2}$ is the most suitable marker. $\mathrm{TiO}_{2}$ at $1 \mathrm{~g} / \mathrm{kg}$ gave the smallest difference between the faecal digestibility of $\mathrm{N}$ and amino acids determined by total faecal collection and by the use of markers. Therefore, the most suitable level of $\mathrm{TiO}_{2}$ was $1 \mathrm{~g} / \mathrm{kg}$ diet.

The authors wish to acknowledge Dr W. Haresign for surgery, the skilled technical assistance of Kathy Wagg, Daisy Sketchley, David Bozon and the financial support of the Ministry of Agriculture, Fisheries and Food.

\section{REFERENCES}

Agricultural Research Council (1981). The Nutrient Requirements of Pigs. Slough: Commonwealth Agricultural Bureaux.

Barnicote, C. R. (1945). Estimation of apparent digestibility coefficients by means of an inert reference substance. New Zealand Journal of Science and Technology A 27, 202-212.

Bech-Anderson, S. (1979). Single-column analysis of amino acids in hydrolysates containing chromic oxide. Joumal of Chromatography 179, 227-228. 
Buttery, P. J. \& Soar, J. B. (1975). A spectrofluorimetric assay of the tryptophan content of feedstuffs. Journal of the Science of Food and Agriculture 26, 1273-1277.

Corring, T. (1980). Endogenous secretions in the pig. In Current Concepts of Digestion and Absorption in Pigs, pp. 136-150 [A. G. Low and I. G. Partridge, editors]. Reading: National Institute for Research in Dairying.

Fenton, T. W. \& Fenton, M. (1979). An improved procedure for the determination of chromic oxide in feed and feces. Canadian Journal of Animal Science 59, 631-634.

Jagger, S. (1987). Ileal digestibility of pig diets. PhD Thesis, University of Nottingham.

Kane, E. A., Jacobsen, W. C. \& Moore, L. A. (1950). A comparison of techniques used in digestibility studies with dairy cattle. Journal of Nutrition 41, 583-596.

Kotb, A. R. \& Luckey, T. D. (1972). Markers in nutrition. Nutrition Abstracts and Reviews 42, 813-845.

Leone, J. L. (1973). Collaborative study of the quantitative determination of titanium dioxide in cheese. Journal of the Association of Official Analytical Chemists 56, 535-537.

Lloyd, L. E., Rutherford, B. E. \& Crampton, E. W. (1955). A comparison of titanic oxide and chromic oxide as index materials for determining apparent digestibility. Journal of Nutrition 56, 265-27!.

Low, A. G. (1982). Digestibility and availability of amino acids from feedstuffs for pigs: a review. Livestock Production Science 9, 511-520.

Marsden, M. (1984). Amino acid metabolism in the rumen. PhD Thesis, University of Nottingham.

Maynard, L. A., Loosli, J. K., Hintz, H. F. \& Warner, R. G. (1979). Animal Nutrition, 7th ed. London: McGrawHill Book Company.

Moore, J. H. (1957). Diurnal variations in the composition of faeces of pigs on diets containing chromium oxide. British Journal of Nutrition 11, 173-288.

Moore, J. H. (1959). The use of indicators in digestibility studies. Agricultural Progress 34, $48-63$.

Morgan, D. J. (1972). Energy values in pig nutrition. PhD Thesis, University of Nottingham.

Njaa, L. R. (1961). Determination of protein digestibility with titanium oxide as indicator substance. Acta Agriculturae Scandinavica 11, 227-241.

Peddie, J., Dewar, W. A., Gilbert, A. B. \& Waddington, D. (1982). The use of titanium dioxide for determining apparent digestibility in mature domestic fowls (Gallus domesticus). Journal of Agricultural Science, Cambridge 99, 233-236.

Peers, D. G., Taylor, A. G. \& Whittemore, C. T. (1977). The influence of feeding level and level of dietary inclusion on the digestibility of barley meal in the pig. Animal Feed Science and Technology 2, 41-47.

Rowell, J. G. \& Walters, D. E. (1976). Analysis of data with repeated observations on each experimental unit. Journal of Agricultural Science, Cambridge 87, 423-432.

Steele, W. \& Clapperton, J. L. (1982). The use of chromic oxide as a food marker - a warning. Journal of the Science of Food and Agriculture 33, 325-328.

Tanksley, T. D. Jr, Knabe, D. A., Purser, K., Zebrowska, T. \& Corley, J. R. (1981). Apparent digestibility of amino acids and nitrogen in three cottonseed meals and one soybean meal. Journal of Animal Science $\mathbf{5 2}$, $769-777$.

Taylor, J. (1973). The analysis of designed experiments with censored observations. Biometrics 29, 35-43.

Van Soest, P. J. (1963). Use of detergents in the analysis of fibrous feeds. I1. A rapid method for the determination of fibre and lignin. Journal of the Association of Official Analytical Chemists 46, 829-835.

Wishart, J. (1938). Growth rate determinations in nutrition studies with the bacon pig and their analysis. Biometrika 30, 16-28. 